\title{
Performance of Egg-Shell and Fish-Scale as Adsorbent Materials for Chromium (VI) Removal from Effluents of Tannery Industries in Eastern Uganda
}

\author{
Sam Bamukyaye, William Wanasolo \\ Department of Chemistry, Kyambogo University, Kampala, Uganda \\ Email: bamukyaye@yahoo.com,wanasolo@gmail.com
}

How to cite this paper: Bamukyaye, S. and Wanasolo, W. (2017) Performance of EggShell and Fish-Scale as Adsorbent Materials for Chromium (VI) Removal from Effluents of Tannery Industries in Eastern Uganda. Open Access Library Journal, 4: e3732.

https://doi.org/10.4236/oalib.1103732

Received: June 9, 2017

Accepted: August 13, 2017

Published: August 16, 2017

Copyright ( $\odot 2017$ by authors and Open Access Library Inc.

This work is licensed under the Creative Commons Attribution International License (CC BY 4.0).

http://creativecommons.org/licenses/by/4.0/

\begin{abstract}
The performance of egg-shells and fish-scales biomaterials in separating chromium (VI) ions from tannery effluents obtained from tannery industries in Jinja town of Eastern Uganda was investigated. Using crushed egg-shell and fish-scales as adsorbents, sorption tests were carried out to determine the effects of bio-sorbent concentration and particle size on chromium (VI) removal. The adsorbate concentration in the tannery effluents before and after adsorption was analyzed using the UV-vis Spectrophotometer at wavelength of $540 \mathrm{~nm}$. The adsorbent concentration was calculated from concentration change in aqueous solution before and after equilibrium sorption. Results showed that chromium (VI) ions adsorb on the surfaces of both biomaterials. The optimum conditions for chromium (VI) removal were found at $\mathrm{pH}$ of 6.8, particle size of $300 \mu \mathrm{m}$ and bio-sorbent concentration of $0.5 \mathrm{~g}$. The correlation coefficient $\left(\mathrm{R}^{2}\right)$ showed that chromium (VI) adsorption fitted Langmuir adsorption isotherms. It was concluded that the adsorption process of chromium (VI) on the fish-scales and egg-shells was highly feasible.
\end{abstract}

\section{Subject Areas}

Analytical Chemistry, Environmental Chemistry

\section{Keywords}

Tannery Effluents, Chromium (VI) Removal, Egg-Shell, Fish-Scales, Biomaterials

\section{Introduction}

Leather tanning is important for converting hides and skins into usable materials 
for production of leather based products. The tannery industry is one of the most chemical and water intensive industries [1]. The industry is also associated with a number of environmental and human health risks, including cancer among tannery workers [2]. In Uganda, working in a leather tanning industry involves exposure risks to a wide range of chemicals, some of have carcinogenic and mutagenic properties.

A significant number of operations within a tannery industry are wet operations that consume large amounts of water, chemicals and energy, and resulting in production of large amounts of polluted effluents. The effluents often contain considerable amounts of heavy metals that endanger public health and the environment if discharged without adequate treatment [3]. This happened to be a common practice in tannery industries found in Jinja town, eastern Uganda. One of the heavy metals that have generated international concern is chromium generated from the chrome based tannery industries. Chromium exists in several chemical forms and oxidation states ranging from (0) to (VI). However, only two forms, chromium (III) and chromium (VI) are stable enough to occur in the environment [4]. Chromium compounds in the form of Chromium (III) are used in the tanning process; mainly because chrome tanned leather possess top handling quality, high hydrothermal stability and other excellent user properties [5]. Despite these advantageous, there are several challenges associated with chromium removal from tannery wastes causing environmental pollution.

It has been reported that conventional chromium removal methods are not environmentally friendly due to the increased level of chemical sludge; energy inputs; and nutrient requirements from the removal processes; making the conventional processes expensive because of the implementation of large infrastructure [6] [7]. Consequently, biosorption offers better alternative to the conventional chromium removal methods because of limited chemical sludge making them environmentally friendly and non-expensive. This is great practical significance to the tannery industry in the region.

Several studies have shown that many materials of bio-origin are effective in adsorbing Chromium from its wastes. For example, Sumathi [8] employed sawdust; rice husk and charcoal as adsorbents for removal of Chromium from tannery effluents. The biosorbents were found to be effective in removing Chromium, implying that the bio-wastes were potential adsorbents for reduction of $\mathrm{Cr}$ from wastewater. Preethi [9] used extracts of various plants for chromium (CrVI) removal from its wastes. Results showed that some plant extracts reduced the CrVI. This suggested a possible application of plant extracts as eco-friendly materials for wastewater treatment. Jain [10] used nitrogen-enriched nano-biopolymer for the removal of $\mathrm{Cr}(\mathrm{VI})$ from tannery effluent. Results showed maximum removal efficiency. Elabbas [11] employed egg-shell and marble to remove $\mathrm{Cr}$ (III) ions from chrome tanning wastes. Results showed that powdered marble adsorbed a larger amount of Cr (III) than egg-shell. Jadhav [12] used Tectona-Grandies leaves as ecofriendly and low-cost adsorbents for Chromium 
(VI) removal from wastewater. Results showed effective removal of the chromium. In this study, egg-shells and fish-scales of Nile perch (Lates niloticus sp.) were investigated as biosorbents for chromium sorption capabilities under different biosorbent-to-chromium mass ratios and contact times.

\section{Literature Review}

Many types of biomass materials have been investigated as adsorbents for removal of heavy metals from waste waters [13] [14] [15] [16]. Also, fish-scales in fishery waste management have been reported as adsorbents in adsorption processes due to the high binding capacities [17] [18].

Chicken egg-shells as well as fish-scales have also been used as low cost adsorbent of several heavy metal ions [19]. Egg-shell is mainly composed of calcium carbonate and it should behave as other adsorbents that contain this compound, i.e., calcite and calcareous soils. On the other hand fish-scales are a byproduct of fishery; the scales are composed of hydroxyapatite and collagen, forming a natural composition with a large specific surface area that intensifies the adsorption process [20]. Adsorption using natural materials can be an efficient technology compared to that which employs synthetic substances. In particular, egg-shells and fish-scales natural materials are reported to contain high adsorptive properties for the removal of metallic ions from water [21].

However little information is available on how effective the egg-shells and fish-scales are in removing chromium from polluted effluents. This study was intended to evaluate the effectiveness of egg-shells and fish-scales in removing chromium from tannery effluents. Additionally, tannery effluents contain large quantities of organic and inorganic compounds including toxic substances such as chromium salts. Poorly treated tannery effluents leads to wide spread contamination of food chains, sharp decline in productivity of food crops, soil, vegetables, livestock and even milk production.

One of the most widely used synthetic adsorbents is activated carbon since it offers fast kinetics and low cost. Others include silica gel and alumina which have enormous surface areas per unit weight [22].

Adsorption is one of the promising physical processes that can remove heavy metals from water. The process is suitable even when the metal ions are present in concentration as low as $1 \mathrm{mg} / \mathrm{L}$ [23]. Activated carbon has been used for the removal of $\mathrm{Pb}, \mathrm{Cd}$ and other heavy metals especially when associated with organic particulates in water [24]. Hydroxides of Alumina and Iron have also been used as adsorbents for the removal of heavy metals [16]. Unfortunately, the cost of these synthetic adsorbent is high. There is, therefore, an increasing trend for substituting the pure synthetic adsorbents with naturally occurring bio-materials in order to make the adsorption process economically feasible.

The bio-materials or biosorbents include algal biomass, fungi, and peat moss among others. The advantages of biosorbents are: low cost, high efficiency of heavy metal removal from dilute solutions, regeneration and possible metal recovery [16]. It has been reported that the algal biomass of the Sargassum family 
possesses a metal binding capacity superior to inorganic adsorbents [25]. Consequently, brown marine macro-algae were used to remove Cd (II) [26]. However, the direct application of live biosorbents for heavy metal removal is unfavorable due to the resistance of living cells to metal ions.

\section{Materials and Methods}

The two different adsorbents used in this study were low-cost powdered eggshells and fish-scales. The egg-shells were collected from hotels around Kampala, while the waste fish-scales were collected from a fish processing plant. These adsorbents were washed with tap water several times to remove adhering dust and soluble impurities from their surface and rinsed with de-ionized water. The materials were dried in an oven at temperature of $40^{\circ} \mathrm{C}$ to a constant weight. The dried materials were then converted to $300-600 \mu \mathrm{m}$ mesh powder by grinding in a mechanical grinder and preserved in polythene containers for subsequent use as adsorbents.

Chrome effluents containing chromium (VI) was obtained from two different tannery industries and collected in plastic containers. The effluent samples from the two tannery industries were labeled as effluent-1 (from Leather Industries of Uganda) and effluent-2 (from Sky Fat Tannery). The samples were collected from predefined sites using grab method. Three samples were collected at different time intervals (in the morning, midday and in the afternoon) from each industry giving a total of six samples per day. Sampling time was synchronized with the discharging time of the tannery effluents from the industries. The three samples collected for each industry per day were mixed in equal proportions in a $2000 \mathrm{~mL}$ high density polyethylene bottle. The $\mathrm{pH}$ was recorded and the samples were transferred to the laboratory in plastic bottles and preserved with $2 \mathrm{~mL}$ of nitric acid and stored at $4^{\circ} \mathrm{C}$.

\subsection{Sample Characterization}

The collected raw effluent samples had a dark green color. This indicated the presence of chromium (III). It was therefore necessary to convert the chromium (III) to chromium (VI). This was accomplished by oxidation with potassium permanganate using APHA method and the color intensity was measured spectrophotometrically using a UV-1700 Spectrophotometer.

\subsection{Determination of Adsorbent Particle Size}

The influence of adsorbent particle size on the chromium adsorption was studied using 300, 425 and $600 \mu \mathrm{m}$ particle sizes. These particle sizes were found to be more efficient from preliminary experimentation.

\subsection{Adsorbent Dose}

The mass of the dry adsorbent (egg-shells and fish-scales) were varied from 0.05 to $1.0 \mathrm{~g}$. The desired mass was placed in a flask with $100 \mathrm{~mL}$ of effluent at $\mathrm{pH} 6.8$ 
for 6 hours. The mixture was shaken using flask shaker at $300 \mathrm{rpm}$ and $25^{\circ} \mathrm{C}$. The uptake of chromium (VI) was determined from residual concentration of chromium (VI) in the supernatant.

\subsection{Contact Time}

A $0.5 \mathrm{~g}$ portion of dry adsorbent was placed in each flask containing $100 \mathrm{~mL}$ of effluent at $\mathrm{pH}$ 6.8. The contents of the flasks were equilibrated on the flask shaker at $300 \mathrm{rpm}$ for $20,40,60,80,100,120,140,160,180,200,220$ and $240 \mathrm{mi}-$ nutes. The treated effluent was filtered and the chromium (VI) concentration was determined.

\subsection{Initial Concentration of Chromium (VI)}

Portions of $0.5 \mathrm{~g}$ dry adsorbents (egg-shells and fish-scales) were placed in a series of flasks containing $100 \mathrm{~mL}$ of prepared effluent samples of different initial concentrations at $\mathrm{pH} \mathrm{6.8.} \mathrm{The} \mathrm{contents} \mathrm{of} \mathrm{the} \mathrm{flasks} \mathrm{were} \mathrm{shaken} \mathrm{at} 300 \mathrm{rpm}$ and $25^{\circ} \mathrm{C}$ for 6 hours. At equilibrium, the residual concentration of chromium (VI) was determined and the amount adsorbed was computed.

\section{Results and Discussion}

The data was collected from runs for each of the adsorbents and the effluents; followed by plots for percent removal. Using chromium standard solutions, a calibration curve was obtained with the help of the Spectrophotometer.

\subsection{Effect of Adsorbent Particle Size on Chromium Removal}

The data for effect of different adsorbent particle sizes on percentage removal of chromium (VI) is shown in Table 1. The data shows that adsorption of chromium (VI) on egg-shell and fish-scale powder decreased with the increase in particle size for all initial concentrations. The level of adsorption was generally proportional to specific surface area. This result was consistent with that reported by Aliabadi et al., [27], where the chromium (VI) removal at different particle sizes increased with decrease in particle size of adsorbent.

\subsection{Effect of $\mathrm{pH}$}

Data for effect of $\mathrm{pH}$ on the adsorption of chromium (VI) ions is shown in Figure 1. The data shows that adsorption capacity of chromium (VI) ions on

Table 1. Average percentage removal of chromium (VI) at different particle sizes.

\begin{tabular}{cccc}
\hline \multirow{2}{*}{ Adsorbent plus effluent sample } & \multicolumn{3}{c}{ Particle size $( \pm 0.5 \mu \mathrm{m})$} \\
\cline { 2 - 4 } & 300 & 425 & 600 \\
\hline Effluent-1/Egg-shell & 54.43 & 50.63 & 46.83 \\
Effluent-1/Fish-scale & 51.89 & 48.10 & 37.97 \\
Effluent-2/Egg-shell & 14.46 & 13.25 & 8.43 \\
Effluent-2/Fish-scale & 13.25 & 7.23 & 6.63 \\
\hline
\end{tabular}




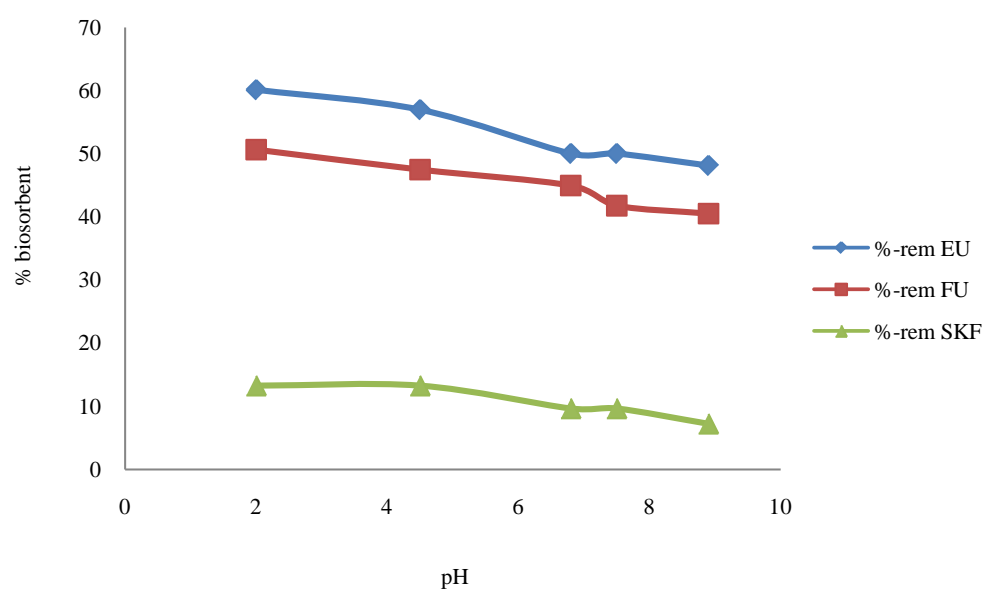

Figure 1. The effect of $\mathrm{pH}$ on Chromium (VI) adsorption.

egg-shells and fish-scale powder was maximum at $\mathrm{pH} 2.0$ and decreases with increase in $\mathrm{pH}$ up to 8.9. At $\mathrm{pH}$ values of 2 and 8.9, corresponding uptake yield values were found to be $60.12 \%$ and $48.1 \%$, respectively, for egg-shell powder; and $50.63 \%$ and $40.51 \%$, respectively, for fish-scale powder.

The metal adsorption dependence on $\mathrm{pH}$ can largely be attributed to the type and ionic state of the functional group present in the adsorbent and also to the metal chemistry in the solution [28]. High adsorption of chromium (VI) at low $\mathrm{pH}$ can be attributed to particular chromium species and the adsorbent surface. At low $\mathrm{pH}$, the predominant chromium species are $\mathrm{Cr}_{2} \mathrm{O}_{7}^{2-}, \mathrm{HCrO}_{4}^{-}, \mathrm{Cr}_{3} \mathrm{O}_{10}^{2-}$ and $\mathrm{Cr}_{4} \mathrm{O}_{13}^{2-}$ [29]. Above $\mathrm{pH}$ of 8 , only $\mathrm{CrO}_{4}^{2-}$ is stable and as the $\mathrm{pH}$ decreases it changes to the dichromate. On the other hand, under low $\mathrm{pH}$ values, the adsorbent surface becomes highly protonated and favors the uptake of chromium (VI) in the anionic form. With increase in $\mathrm{pH}$, the degree of protonation of the surface reduces gradually, resulting in decreased adsorption [30]. As the $\mathrm{pH}$ is increased further, there is competition between $\mathrm{OH}^{-}$and chromate ions $\left(\mathrm{CrO}_{4}^{2-}\right)$, the former being the dominant species at higher $\mathrm{pH}$ values. The net positive surface potential of the adsorbent decreases, resulting in the weakening of electrostatic forces between adsorbent and adsorbate, which ultimately leads to reduced sorption capacity.

\subsection{Effect of Dosage}

The effect of adsorbent dosage on sorption of chromium (VI) is shown in Figure 2. When adsorbent dosage was increased from 0.05 to $0.5 \mathrm{~g}$, as determined from preliminary experimentation; at constant $\mathrm{pH}$ of 6.8 the chromium (VI) adsorbed increased from $48.1 \%$ to $60.1 \%$ for egg-shell and from $55.96 \%$ to $60.1 \%$ for fishscale in effluent-1. While for Sky fat it increased from $7.23 \%$ to $15.66 \%$ for eggshell and from $8.43 \%$ to $15.45 \%$ for fish-scale powder. This implied that adsorbent dosage enhanced chromium (VI) removal from tannery effluents. The increase in chromium (VI) adsorption with adsorbent dosage could be attributed to increased surface area and also availability of more binding sites. When the 


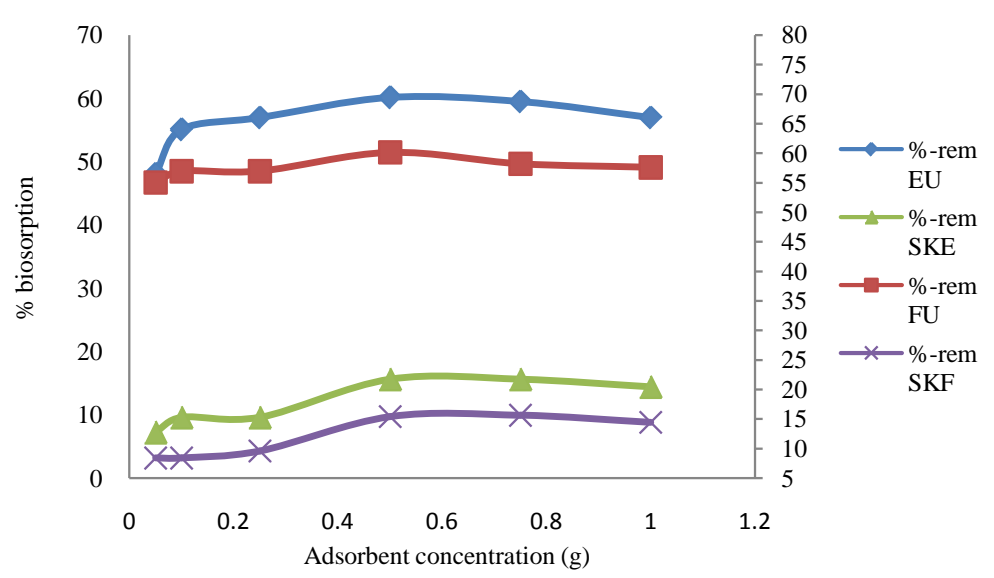

Figure 2. Effect of adsorbent dosage on adsorption of chromium (VI).

adsorbent powders were mixed with the effluent solution, the calcium salts in the adsorbent partially dissolved and released $\mathrm{Ca}^{2+}, \mathrm{HCO}_{3}^{-}, \mathrm{CO}_{3}^{2-}$ and $\mathrm{OH}^{-}$ ions causing the solution to become basic and forming negative charges on adsorbent surfaces. As the egg-shell dosage was increased, the solution became more basic and the surface area together with negative charge increased, thus, adsorption of chromium (VI) decreased. This was in agreement with literature findings by Arunlertaree et al., [31].

The percentage removal decreased slightly at higher dosage (up to $1 \mathrm{~g} / 100$ $\mathrm{mL}$ ) of the adsorbent. It could be attributed to the fact that at higher dosage the particles aggregate, overlapping and overcrowding, resulting in a decreased surface area as well as decreased adsorption capacity. The effect of diverse ions commonly present in industrial effluents was studied by El-Sheikh and Sweileh [32]. Results revealed a $10 \%$ to $15 \%$ drop is percent recovery of analytes in the presence of certain inorganic and organic anions. Compared to this, it was possible that effluent-2 samples contained more inorganic and organic anions that lowered adsorption due to precipitate or chelate formation with different adsorption sites on the adsorbents. The increase in percent removal was also consistent with results by Kara and Demirbel [33]; and Govindarajan et al., [34] who reported that the percentage removal increased with increasing adsorbent dosage.

\subsection{Effect of Initial Chromium Concentration}

The removal of chromium (VI) was determined at $25^{\circ} \mathrm{C}$ for different concentrations in the range from $7.0 \times 10^{-2} \mathrm{mg} \cdot \mathrm{L}^{-1}$ to $30 \times 10^{-2} \mathrm{mg} \cdot \mathrm{L}^{-1}$ for effluent- 1 and from $6.0 \times 10^{-2} \mathrm{mg} \cdot \mathrm{L}^{-1}$ to $14 \times 10^{-2} \mathrm{mg} \cdot \mathrm{L}^{-1}$ for effluent- 2 at constant $\mathrm{pH}$ of 6.8 and 150 min contact time. The data is shown in Figure 3. The data showed that adsorption decreased to a certain level, remained almost constant and finally decreased further with increasing initial chromium (VI) concentration. This could be attributed to formation of monolayer followed by multilayer. The intermediate flat regions in the curves correspond to layer formation. This can be ex- 


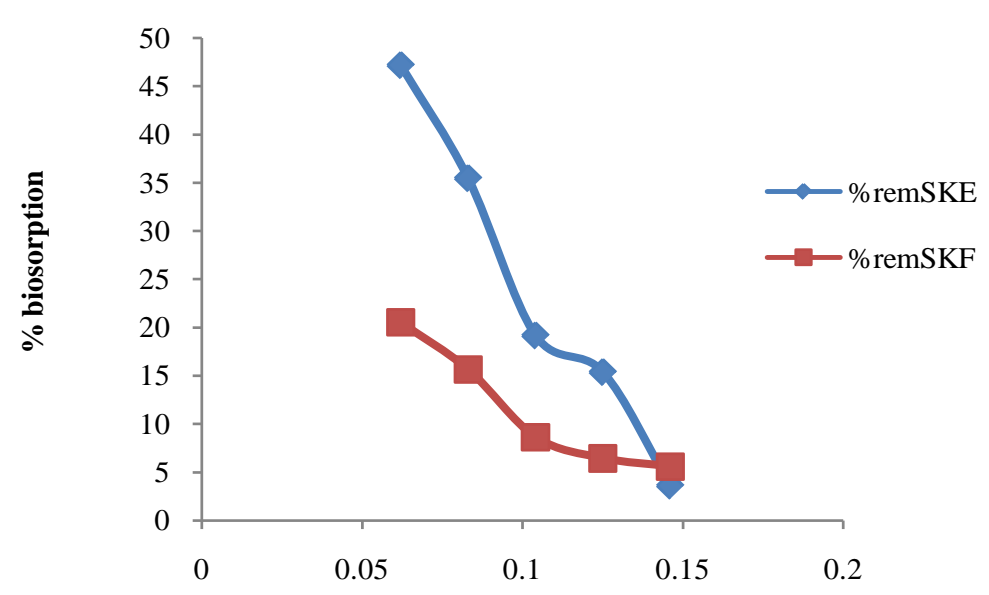

Metal concentration

Figure 3. Effect of metal concentration on adsorption of chromium (VI)

plained on the basis of a possibility of the adsorbate getting taken up in the tiny capillary pores of adsorbent at a concentration below saturation of the adsorbate.

It was also observed that percentage adsorption removal rapidly decreased with increase in adsorbate concentration. This could be explained by the fact that further increase in the concentration of chromium (VI) ion could lead to a decrease in the percentage removal as the active sites were already occupied, hence more metal ions remained in solution after adsorption. Similar results were observed by Dawodu et al. [35].

\subsection{Effect of Contact Time}

The data for effect of contact time on adsorption of chromium (VI) is shown in Figure 4. The data showed that adsorption of chromium (VI) gradually increased with contact time. Also, the time required to reach equilibrium conditions appeared to be independent of initial chromium (VI) concentrations. In addition, it can be seen that the percentage adsorption of chromium (VI) from effluent-2 was much lower than that for effluent- 1 . This was probably due to the presence of other inorganic and organic anions in effluent-2. El-Sheikh and Sweileh [32] noted that there is usually a $10 \%$ to $15 \%$ drop in recovery of analytes in the presence of certain inorganic and organic anions that may cause formation of precipitates and/or chelates with the adsorbent materials

\subsection{Comparison with Other Adsorbents}

The adsorption capacities of the prepared adsorbents were compared with other adsorbents reported in the literature and shown in Table 2. Data from the present study was not different from literature values. This comparison established the validity and applicability of the powdered egg-shells and fish-scales as potential low-cost adsorbents in removing of chromium (VI) from tannery effluents. The adsorption capacities varied and depended on the properties of in- 


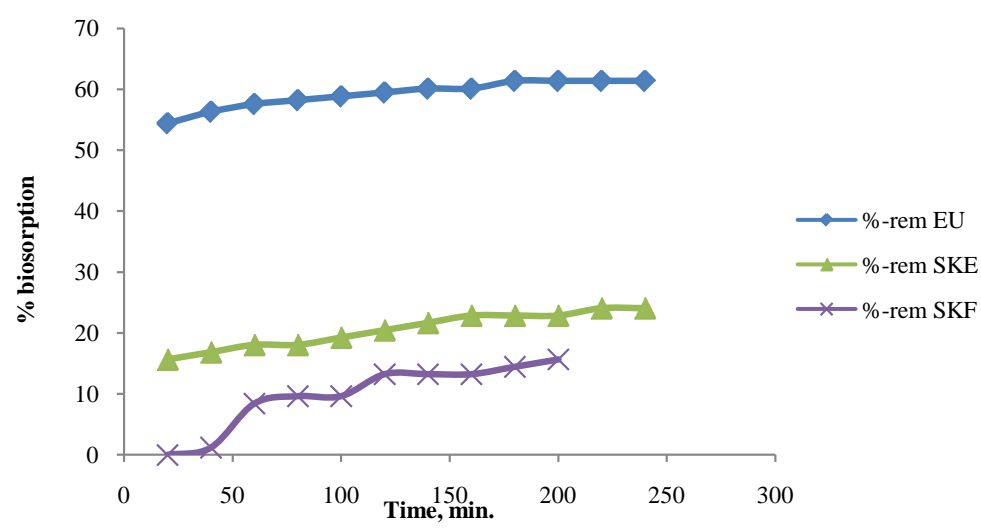

Figure 4. Effect of contact time on adsorption of chromium (VI).

Table 2. Comparison of chromium (VI) adsorption with other adsorbents in literature.

\begin{tabular}{|c|c|c|c|c|}
\hline Adsorbents & $\begin{array}{l}\text { Adsorption capacity } \\
(\mathrm{mg} / \mathrm{g})\end{array}$ & $\begin{array}{l}\text { Initial chromium } \\
\text { conc } \mathrm{mg} / \mathrm{L}\end{array}$ & $\mathrm{pH}$ & Reference \\
\hline $\begin{array}{l}\text { Synthetic nano size } \\
\text { zero valent iron }\end{array}$ & 17.240 & 1 to 30 & 7.0 & $\begin{array}{l}\text { Rahmani, Samadi and } \\
\text { Noroozi [36] }\end{array}$ \\
\hline Saw dust & 0.198 & 1 to 10 & 5.0 & $\begin{array}{c}\text { Aliabadi, Morshedzadeh } \\
\text { \& Soheyli [27] }\end{array}$ \\
\hline Pine leaves & 0.470 & 1 to 10 & 5.0 & $\begin{array}{c}\text { Aliabadi, Morshedzadeh } \\
\text { \& Soheyli [27] }\end{array}$ \\
\hline $\begin{array}{l}\text { Activated spent } \\
\text { Pleurotus }\end{array}$ & 50.470 & 5 & $2-11$ & $\begin{array}{l}\text { Carol, Kingsley \& } \\
\text { Vincent [37] }\end{array}$ \\
\hline Tea factory waste & 27.240 & & 2.0 & $\begin{array}{c}\text { Malkoc and } \\
\text { Nuhoglu [38] }\end{array}$ \\
\hline $\begin{array}{l}\text { Polyaniline with } \\
\text { rice husk }\end{array}$ & 4.739 & & 3.0 & Kanwal et al., [39] \\
\hline $\begin{array}{c}\text { Polyaniline with rice saw } \\
\text { dust }\end{array}$ & 5.128 & & 3.0 & Kanwal et al., [39] \\
\hline Fish-scales & 27.270 & 0.158 & 2.0 & This study \\
\hline Egg-shells & 10.300 & 0.158 & 2.0 & This study \\
\hline
\end{tabular}

dividual adsorbents, initial adsorbate concentration and other factors.

\section{Conclusion}

A number of conclusions were arrived at from the study. It was concluded that the adsorption of chromium (VI) on egg-shell and fish-scale powder decreased with the increase in particle size for all initial concentrations. Also, the adsorption of chromium (VI) ions on egg-shells and fish-scale powders decreases with increased $\mathrm{pH}$ up to 8.9. The adsorbent dosage enhances chromium (VI) removal from tannery effluents. Furthermore, it was concluded that the adsorption of chromium (VI) on egg-shell and fish-scale adsorbents increases with contact time. Additionally, the percentage adsorption of chromium (VI) from effluent-2 was much lower than that for effluent-1. Powdered egg-shells and fish-scales can be applied as low-cost adsorbents in treating and removing of chromium (VI) from tannery effluents. Furthermore, the adsorption capacity of chromium (VI) ions on egg-shells and fish-scale powder was favored by acid conditions. This 
idea could be adopted for large scale chromium removal from its wastes. Also, the adsorbent dosage enhances chromium (VI) removal from tannery effluents. It was therefore concluded that chromium removal can be highest with increase in adsorbate concentration. Since contact time also enhanced adsorption of chromium (VI) gradually, it was concluded that to achieve sufficient removal of chromium, the effluent should be left in contact with the adsorbent material long enough to guarantee maximum chromium removal.

\section{Acknowledgements}

The authors would like to express sincere appreciation to the staff of Department of Chemistry, Makerere University, Uganda for their technical support and laboratory work. Special thanks also go to Management of Kyambogo University, Kampala, Uganda, for the financial assistance rendered during the study.

\section{References}

[1] Majouli, A., Tahiri, S., Younssi, S.A., Loukili, H. and Albizane, A. (2012) Treatment of Effluents Coming from Beamhouse Section of Tannery by Microfiltration through Cordierite/Zirconia and Alumina Tubular Ceramic Membranes. Journal of Materials and Environmental Science, 3, 808-815.

[2] Durai, G. and Rajasimman, M. (2011) Biological Treatment of Tannery Wastewater-A Review. Journal of Environmental science and Technology, 4, 1-17. https://doi.org/10.3923/jest.2011.1.17

[3] Murugananthan, M., Raju, G.B. and Prabhakar, S. (2004) Separation of Pollutants from Tannery Effluents by Electro Flotation. Separation and Purification Technology, 40, 69-75.

[4] Kotaś, J. and Stasicka, Z. (2000) Chromium Occurrence in the Environment and Methods of Its Speciation. Environmental Pollution, 107, 263-283.

[5] Ludvik, J. and Buljan, J. (2000) Chrome Management in the Tanyard. United Nations Industrial Development Organization.

[6] Dixit, S., Yadav, A., Dwivedi, P.D. and Das, M. (2015) Toxic Hazards of Leather Industry and Technologies to Combat Threat: A Review. Journal of Cleaner Production, 87, 39-49.

[7] Saxena, G., Chandra, R. and Bharagava, R.N. (2016) Environmental Pollution, Toxicity Profile and Treatment Approaches for Tannery Wastewater and Its Chemical Pollutants. Reviews of Environmental Contamination and Toxicology, 240, 31-69.

[8] Sumathi, K., Mahimairaja, S. and Naidu, R. (2005) Use of Low-Cost Biological Wastes and Vermiculite for Removal of Chromium from Tannery Effluent. Bioresource Technology, 96, 309-316.

[9] Preethi, J., Chitra, L., Vennila, K., Penislusshiyan, S., Vijayan, R., Sudha, V., et al. (2017) Plant Extract as Environmental-Friendly Green Catalyst for the Reduction of Hexavalent Chromium in Tannery Effluent. Environmental Technology, 1-8.

[10] Jain, P., Varshney, S. and Srivastava, S. (2017) Application of Nitrogen-Enriched Nanobiopolymer for the Effective Removal of Cr (VI) from Tannery Effluent. Separation Science and Technology, 52, 1572-1582. https://doi.org/10.1080/01496395.2017.1295993

[11] Elabbas, S., Mandi, L., Berrekhis, F., Pons, M.N., Leclerc, J.P. and Ouazzani, N. 
(2016) Removal of Cr (III) from Chrome Tanning Wastewater by Adsorption Using Two Natural Carbonaceous Materials: Eggshell and Powdered Marble. Journal of Environmental Management, 166, 589-595.

[12] Jadhav, A.S. and Bamane, S.R. (2016) Removal of Chromium (VI) from Tannery Effluent by Using Tectona-Grandis Leaves as Low Cost Bio Adsorbent: An Environmental Approach. IJAR, 2, 724-728.

[13] Hassan Khani, M., Reza Keshtkar, A., Meysami, B., Firouz Zarea, M. and Jalali, R. (2006) Biosorption of Uranium from Aqueous Solutions by Nonliving Biomass of Marinealgae Cystoseira Indica. Electronic Journal of Biotechnology, 9. https://doi.org/10.2225/vol9-issue2-fulltext-8

[14] Hussain, M.A., Salleh, A. and Milow, P. (2009) Characterization of the Adsorption of the Lead (II) by the Nonliving Biomass Spirogyra neglecta (Hasall) Kützing. American Journal of Biochemistry and Biotechnology, 5, 75-83. https://doi.org/10.3844/ajbbsp.2009.75.83

[15] Ahmad Khan, N., Ibrahim, S. and Subramaniam, P. (2004) Elimination of Heavy Metals from Wastewater Using Agricultural Wastes as Adsorbents. Malaysian Journal of Science, 23, 43-51.

[16] Khan, M.A., Rao, R.A.K. and Ajmal, M. (2008) Heavy Metal Pollution and Its Control through Nonconventional Adsorbents (1998-2007): A Review. Journal of International Environmental Application and Science, 3, 101-141.

[17] Liu, W., Zhang, Y., Li, G., Miao, Y. and Wu, X. (2008) Structure and Composition of Teleost Scales from Snakehead Channa argus (Cantor) (Perciformes: Channidae). Journal of Fish Biology, 72, 1055-1067. https://doi.org/10.1111/j.1095-8649.2007.01790.x

[18] Stepnowski, P., Ólafsson, G., Helgason, H. and Jastorff, B. (2004) Preliminary Study on Chemical and Physical Principles of Astaxanthin Sorption to Fish Scales towards Applicability in Fisheries Waste Management. Aquaculture, 232, 293-303.

[19] Mustafiz, S. (2003) The Application of Fish Scales in Removing Heavy, Metals from Energy-Produced Waste Streams: The Role of Microbes. Energy Sources, 25, $905-$ 916. https://doi.org/10.1080/00908310390221255

[20] Yamamura, A.P. and Yamaura, M. (2007) Preparation and Evaluation of Adsorption Properties of the Magnetic Bagasse. Proceeding of 2007 International Nuclear Atlantic Conference, Santos, 30 September-5 October 2007.

[21] Das, N., Karthika, P., Vimala, R. and Vinodhini, V. (2008) Use of Natural Products as Biosorbent of Heavy Metals-An Overview. Natural Product Radiance, 7, 133 138.

[22] Rao, R., Ikram, S. and Ahmad, J. (2011) Adsorption of Pb (II) on a Composite Material Prepared from Polystyrene-Alumina and Activated Carbon: Kinetic and Thermodynamic Studies. Journal of the Iranian Chemical Society, 8, 931-943. https://doi.org/10.1007/BF03246548

[23] Najim, T.S., Elais, N.J. and Dawood, A.A. (2009) Adsorption of Copper and Iron Using Low Cost Material as Adsorbent. Journal of Chemistry, 6, 161-168. https://doi.org/10.1155/2009/682568

[24] Gueu, S., Yao, B., Adouby, K. and Ado, G. (2006) Heavy Metals Removal in Aqueous Solution by Activated Carbons Prepared from Coconut Shell and Seed Shell of the Palm Tree. Journal of Applied Sciences, 6, 2789-2793. https://doi.org/10.3923/jas.2006.2789.2793

[25] Kratochvil, D. and Volesky, B. (1998) Biosorption of Cu from Ferruginous Waste- 
water by Algal Biomass. Water Research, 32, 2760-2768.

[26] Lodeiro, P., Barriada, J., Herrero, R. and De Vicente, M.S. (2006) The Marine Macroalga Cystoseira baccata as Biosorbent for Cadmium (II) and Lead (II) Removal: Kinetic and Equilibrium Studies. Environmental Pollution, 142, 264-273.

[27] Aliabadi, M., Morshedzadeh, K. and Soheyli, H. (2006) Removal of Hexavalent Chromium from Aqueous Solution by Lignocellulosic Solid Wastes. International Journal of Environmental Science \& Technology, 3, 321-325. https://doi.org/10.1007/BF03325940

[28] Gupta, V. (2009) Application of Low-Cost Adsorbents for Dye Removal-A Review. Journal of Environmental Management, 90, 2313-2342. https://doi.org/10.1016/j.jenvman.2008.11.017

[29] Raji, C. and Anirudhan, T. (1998) Batch Cr (VI) Removal by PolyacrylamideGrafted Sawdust: Kinetics and Thermodynamics. Water Research, 32, 3772-3780.

[30] Selvi, K., Pattabhi, S. and Kadirvelu, K. (2001) Removal of Cr (VI) from Aqueous Solution by Adsorption onto Activated Carbon. Bioresource Technology, 80, 87-89.

[31] Arunlertaree, C., Kaewsomboon, W., Kumsopa, A., Pokethitiyook, P. and Panyawathanakit, P. (2007) Removal of Lead from Battery Manufacturing Wastewater by Egg Shell. Songklanakarin Journal of Science and Technology, 29, 857-868.

[32] El-Sheikh, A.H. and Sweileh, J.A. (2008) Sorption of Trace Metals on Fish Scales and Application for Lead and Cadmium Pre-Concentration with Flame Atomic Absorption Determination. Jordan Journal of Chemistry, 3, 87-97.

[33] Kara, A. and Demirbel, E. (2012) Kinetic, Isotherm and Thermodynamic Analysis on Adsorption of Cr (VI) Ions from Aqueous Solutions by Synthesis and Characterization of Magnetic-Poly (Divinylbenzene-Vinylimidazole) Microbeads. Water, Air, \& Soil Pollution, 223, 2387-2403. https://doi.org/10.1007/s11270-011-1032-1

[34] Govindarajan, C., Ramasubramaniam, S., Gomathi, T., Devi, A.N. and Sudha, P. (2011) Sorption Studies of Cr (VI) from Aqueous Solution Using NanochitosanCarboxymethyl Cellulose Blend. Archives of Applied Science Research, 3, 127-138.

[35] Dawodu, F., Akpomie, G., Ejikeme, M. and Ejikeme, P. (2012) The Use of Ugwuoba Clay as an Adsorbent for Zinc (II) Ions from Solution. International Journal of Surface Science and Engineering, 3, 13-18.

[36] Rahmani, A., Samadi, M. and Noroozi, R. (2011) Hexavalent Chromium Removal from Aqueous Solutions by Adsorption onto Synthetic Nano Size Zerovalent Iron (nZVI). World Academy of Science, Engineering and Technology, 74, 80-83.

[37] Carol, D., Kingsley, S. and Vincent, S. (2012) Hexavalent Chromium Removal from Aqueous Solutions by Pleurotus ostreatus Spent Biomass. International Journal of Engineering Science and Technology, 4.

[38] Malkoc, E. and Nuhoglu, Y. (2007) Potential of Tea Factory Waste for Chromium (VI) Removal from Aqueous Solutions: Thermodynamic and Kinetic Studies. Separation and Purification Technology, 54, 291-298.

[39] Kanwal, F., Rehman, R., Mahmud, T., Anwar, J. and Ilyas, R. (2012) Isothermal and Thermodynamical Modeling of Chromium (III) Adsorption by Composites of Polyaniline with Rice Husk and Saw Dust. Journal of the Chilean Chemical Society, 57, 1058-1063. https://doi.org/10.4067/S0717-97072012000100022 
Submit or recommend next manuscript to OALib Journal and we will provide best service for you:

- Publication frequency: Monthly

- 9 subject areas of science, technology and medicine

- Fair and rigorous peer-review system

- Fast publication process

- Article promotion in various social networking sites (LinkedIn, Facebook, Twitter, etc.)

- Maximum dissemination of your research work

Submit Your Paper Online: Click Here to Submit

Or Contact service@oalib.com 